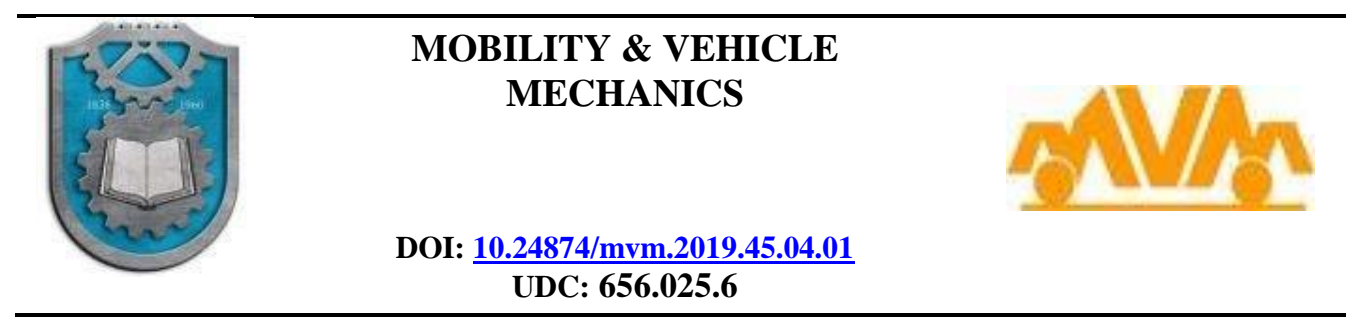

\title{
IMPROVEMENT OF ENERGY EFFICIENCY OF CITY VEHICLE FLEETS: CASE STUDY
}

Davor Končalović ${ }^{1^{*}}$, Dubravka Živković ${ }^{2}$, Dušan Gordić ${ }^{3}$, Vladimir Vukašinović ${ }^{4}$, Mladen Josijević $^{5}$, Slađana Stević ${ }^{6}$

Received in September 2019 Accepted in November 2019

RESEARCH ARTICLE

\begin{abstract}
The subject of this paper are measures for improvement of the energy efficiency of fleets that are in the jurisdiction of the one city in Serbia. Improvement of energy efficiency is proposed thorough following five measures: Data collection, internal benchmarking, transparency, the publication of collected information and rewarding of good practice examples; Creation of a joint fleet, joint driving and driving pairing (car sharing in public institutions); Establishment of eco-driving programs in the City Administration; Tire pressure control and The transition of a part of the petrol fleet to liquid petroleum gas. Here proposed methodology is easily understandable, characterized by transparency and easy adaptation while monitoring the results of the implementation of proposed measures is intuitive and simple.
\end{abstract}

KEY WORDS: fleet management, energy efficiency, energy management system

(C) 2019 Published by University of Kragujevac, Faculty of Engineering

\footnotetext{
${ }^{1}$ Davor Končalović, PhD, assist. prof., University of Kragujevac, Faculty of Engineering, Sestre Janjić 6, 34000 Kragujevac, Serbia, davor.koncalovic@kg.ac.rs (*Corresponding author)

${ }^{2}$ Dubravka Živković, PhD, research assist., University of Kragujevac, Faculty of Engineering, Sestre Janjić 6, 34000 Kragujevac, Serbia, dubravka@kg.ac.rs

${ }^{3}$ Dušan Gordić, PhD, full prof., University of Kragujevac, Faculty of Engineering, Sestre Janjić 6, 34000 Kragujevac, Serbia, gordic@kg.ac.rs

${ }^{4}$ Vladimir Vukašinović, PhD, assist. prof., University of Kragujevac, Faculty of Engineering, Sestre Janjić 6, 34000 Kragujevac, Serbia, vladimir.vukasinovic@kg.ac.rs

${ }^{5}$ Mladen Josijević, Teaching assist., University of Kragujevac, Faculty of Engineering, Sestre Janjić 6, 34000 Kragujevac, Serbia, mladen.josijevic@ fink.rs

${ }^{6}$ Slađana Stević, City Administration for Project Management, Sustainable and Balanced Development, 34000 Kragujevac, Serbia, sstevic@kg.org.rs
} 
The total investment is estimated on less than $100.000 €$, while savings are almost double that value in the first year of implementation of measures, suggesting a large space for energy management measures and that fleets are relatively poorly managed up to date.

\section{POBOLJŠANJE ENERGETSKE EFIKASNOSTI VOZNOG PARKA GRADSKIH VOZILA: STUDIJA SLUČAJA}

REZIME: Predmet ovog rada su mere za poboljšanje energetske efikasnosti voznih parkova koje su u nadležnosti jednog grada u Srbiji. Poboljšanje energetske efikasnosti predlaže se kroz implementaciju pet mera: Prikupljanje podataka, interno vrednovanje, transparentnost, objavljivanje prikupljenih informacija i nagrađivanje primera dobre prakse; Formiranje zajedničkog voznog parka, uspostavljanje zajedničke vožnje i uparivanja automobila (deljenje automobila u javnim institucijama); Uspostavljanje programa ekološke vožnje u Gradskoj upravi; Kontrola pritiska u gumama i Prelaz dela benzinske flote na tečni naftni gas. Ovde predložena metodologija je lako razumljiva, karakteriše je transparentnost i lako prilagođavanje, a praćenje rezultata primene predloženih mera je intuitivno i jednostavno. Ukupna investicija procenjena je na manje od $100.000 €$, dok su očekivane uštede dvostruko veće već u prvoj godini primene mera, što ukazuje na veliki prostor za mere upravljanja energijom kao i da se voznim parkovima do sada relativno loše upravljalo.

KLJUČNE REČI: upravljanje voznim parkom, energetska efikasnost, sistem upravljanja energijom 


\section{IMPROVEMENT OF ENERGY EFFICIENCY OF CITY VEHICLE FLEETS: CASE STUDY}

Davor Končalović, Dubravka Živković, Dušan Gordić, Vladimir Vukašinović, Mladen

Josijević, Slađana Stević

\section{INTRODUCTION}

The subject of this paper is to propose measures to improve the energy efficiency of the vehicle fleets under the jurisdiction of the one Serbian city administration. The administration is responsible for the management of 40 fleets of 40 public utility companies, cultural institutions, agencies, sports institutions, schools, pharmacies, centers and other local government units necessary for the day-to-day operation of city establishments.

Energy consumption by the aforementioned fleets in 2016. are 213,000 litters of gasoline, 726,000 litters of diesel fuel and 52,500 litters of liquefied petroleum gas i.e. around 1.1 million euros in total. Just to illustrate, one percent of energy savings will result in an annual savings of about $€ 11,000$.

The benefits of the approach presented here are reflected in a simplified, easy to understand, graphical representation of the savings potential.

\section{OVERVIEW}

The city administration of the City is (to a greater or lesser extent) responsible for the operation of fleets in a total of 40 public companies with a total of 334 vehicles in the territory of the City (from ownership of vehicles to participation in the management structure of the company/institution). These fleets vary in size between 1 and 55 vehicles, with an average fleet size of 8 vehicles. All vehicles are grouped into followings groups (Figure 1) according to [1]:

- M1 - vehicles intended for the carriage of persons having, in addition to the driver's seat, maximum eight seats (245 vehicles)

- $\quad \mathrm{N} 1$ - vehicles intended for the carriage of goods and having a maximum mass not exceeding 3,5 tonnes (44 units)

- $\quad \mathrm{N} 2$ and N3 - vehicles intended for the carriage of goods and having a maximum mass exceeding 3,5 tonnes but less than 12 tonnes (N2) and vehicles intended for the carriage of goods with a maximum mass exceeding 12 tonnes (N3) (total of 35 vehicles)

- $\quad \mathrm{T}$ - tractors (10 units). 


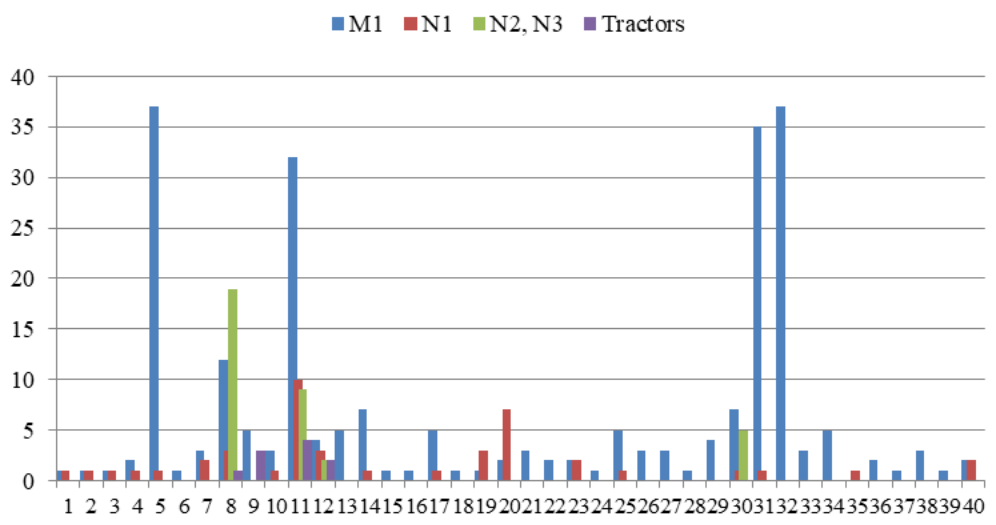

Figure 1. Structure of vehicle fleet by vehicle category

Most vehicles use gasoline (158 vehicles), then diesel (141 vehicles) while the smallest number of vehicles are driven by liquid petroleum gas (35 vehicles) (Figure 2).

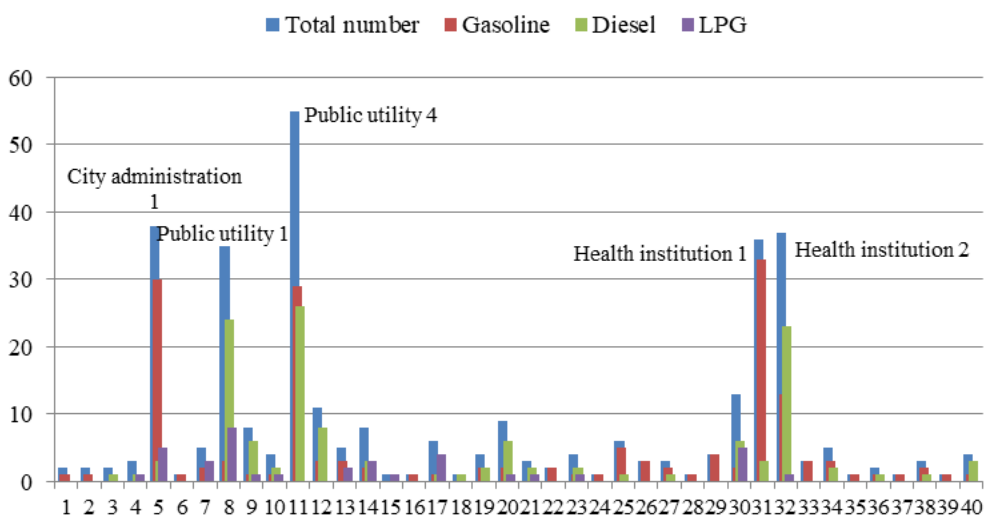

Figure 2. Structure of fleets of public companies by fuel

Vehicles average $11,500 \mathrm{~km}$ a year (2016), i.e. 10,000 km (2015), which is relatively small mileage given the purpose of vehicles (the European average is about 22,000 km per year for similar vehicles). Presence of the vehicles with low mileage suggests:

- High costs per kilometer caused by high fixed costs (maintenance, depreciation, registration and insurance costs)

- inadequate fleet management or inadequately sized vehicle fleet since the average vehicle mileage per day is only $38 \mathrm{~km}$ (for the year that has 260 working days), i.e. if they move at a speed of $50 \mathrm{~km} / \mathrm{h}$ in traffic, cars are running about 45 minutes a day. 


\section{ANALYSIS}

Figure 3 shows the fleets according to the cumulative number of kilometers traveled and the costs for fuels, while the size of the "balloon" corresponds to the size of the vehicle fleet (number of vehicles). The trendline shows that higher costs and more mileage have been driven by fleets of companies with more vehicles, and vice versa. Also, from the diagram, it can be noted that the company "Public Utility 1" deviates significantly from the trend line, which can be explained by the specific nature of the job, the fleet is dominated by trucks, moving at low speeds with frequent stops. For this reason, but also because of the fact that they recently invested in fleet renewal, "Public Utility 1 " will not be the subject of specific measures but only of general measures in this paper. Similar treatment and similar reasons will also exclude two more Public Utility companies (because of the heavy-duty working regimes of vehicles) and one driving school from this analysis. Once measures are implemented and the data collection system is strengthened (and fuel consumption data per vehicle is available), these fleets will be treated like others.

Note: The potential for energy savings in the aforementioned three Public companies and Driving school is large (around 700,000 $€$ per year, i.e. about $70 \%$ of the total energy used by 40 fleets treated here). In addition, only "Public Utility 1" consumes the same amount of fuel as the remaining 39 fleets together, i.e. "Public Utility 1" is responsible for half of the total energy consumed.

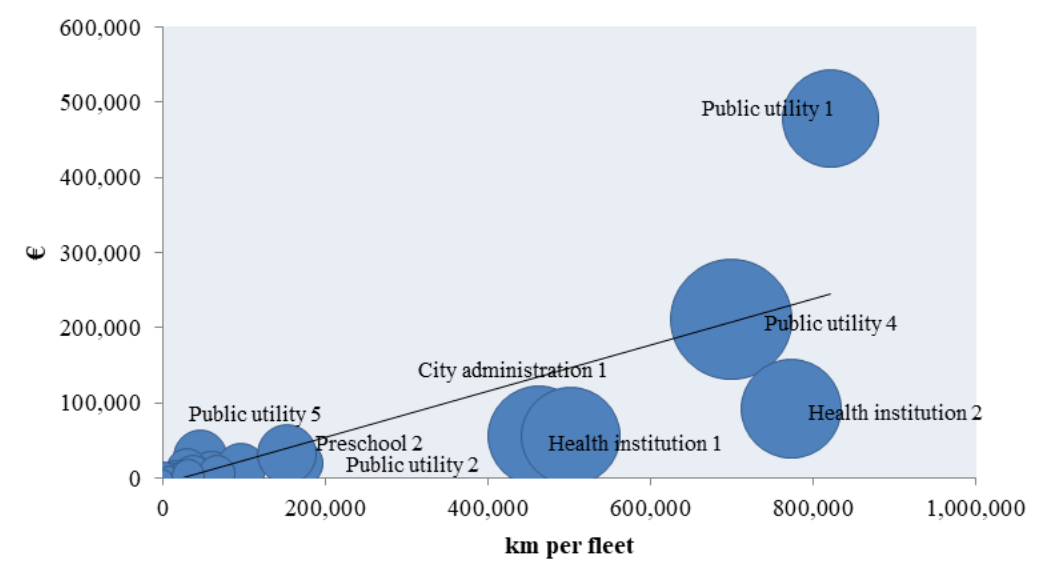

Figure 3. Vehicle fleets according to the cumulative mileage and the fuel costs, while the size of the "balloon" corresponds to the number of vehicles in a fleet

Figure 4 shows a trend line that shows the expected distribution of these sizes. The next few images will show the diagrams that follow from the diagram shown in Figure 10, followed by comments and adequate conclusions. 




Figure 4. Vehicle fleet according to specific indicators (per vehicle)

Figure 5 shows the above-mentioned fleets, this time according to specific indicators. The picture shows the impact that exclusion of the abovementioned three Public Utilities and one Driving School have on the trend line. Clearly, that exclusion resulted in more coherent data that are describing the remaining fleets. In order to reduce the error, the fleet that is on farright down is also removed from the analysis, since it is not possible for a vehicle to have such low operating costs, which, on the other hand, indicates the need for strengthening the data collection system.

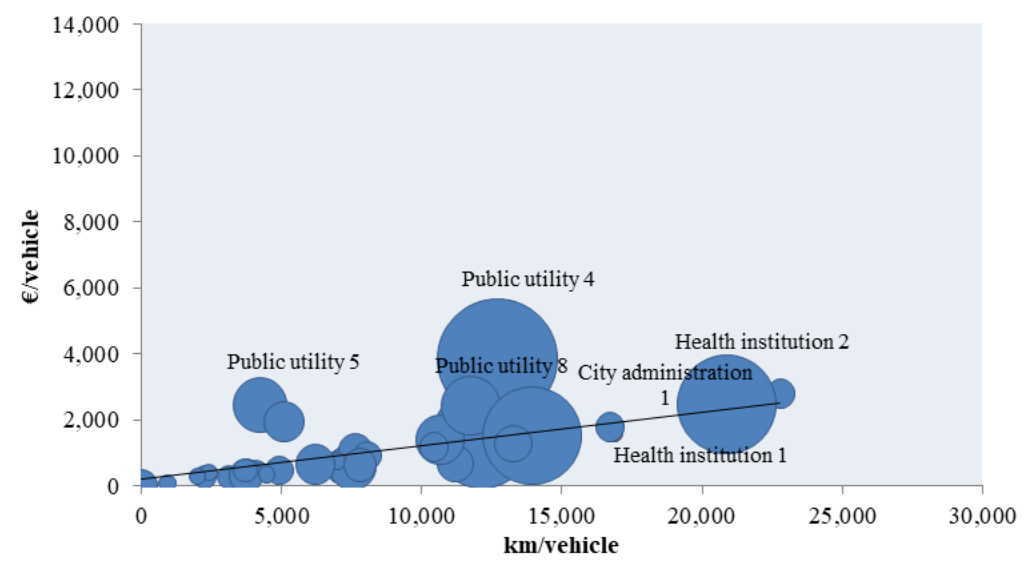

Figure 5. Car parks according to specific indicators (per vehicle) after the exclusion of three public companies

Figure 6 shows the newly emerging situation and the apparent coherence of the data. The trend line now shows a clear dependence between the number of miles traveled per vehicle and fuel costs, also per vehicle. The figure is now showing 36 fleets with a total energy consumption of around $3 \mathrm{GWh}$ in 2016, or 340,000 euros. 


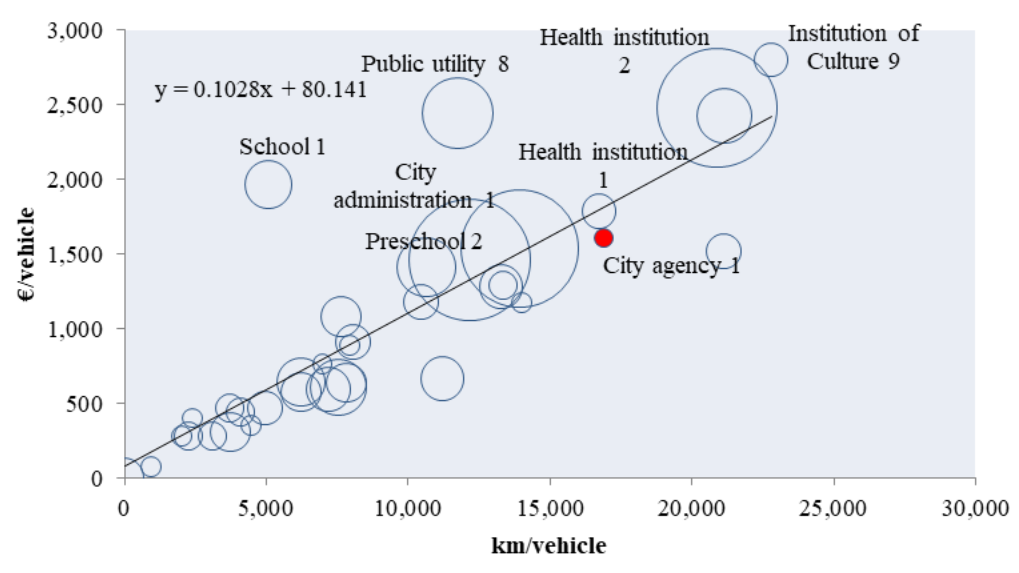

Figure 6. Fleets according to specific indicators (per vehicle) after the correction of the value on the ordinate

Figure 6 is a content identical to Figure 5 with a difference in the maximum values on apices and ordinates. This change provides a better insight into the data, i.e. it emphasizes somewhat smaller and somewhat larger (more significant) deviations from the trend line. The attention should be paid to the trend line and the red dot that presented the proclaimed referent fleet, which is now below the trend line, i.e. the consumption of energy by the vehicles of that fleet is below the average, therefore - an example of good practice. After the implementation of individual measures, this point will change the relative position relative to the trend line, which will be seen in the following Chapter.

\section{RESULTS AND MEASURES PROPOSED}

Improvement of energy efficiency is proposed through five measures, loosely based on [2, 3]:

- Data collection, internal benchmarking, transparency, the publication of collected information and rewarding of good practice examples

- Creation of a joint fleet, joint driving and driving pairing (car sharing in public institutions)

- Establishment of eco-driving programs in the City Administration

- Tire pressure control

- The transition of a part of the petrol fleet to liquid petroleum gas.

\subsection{Measure 1: Data collection, internal benchmarking, transparency, the publication of collected information and rewarding of good practice examples}

By analyzing the situation in Figure 6, it can be noticed that a group of fleets is located on the upper side of the trend line, i.e. represent a significant potential for energy savings in relation to the group of fleets that are located on the underside of the trendline. The potential savings that come from approaching the trend line of fleets that are now above the trend line is $€ 62,000$, i.e. about $6 \%$ of the total energy consumed. 


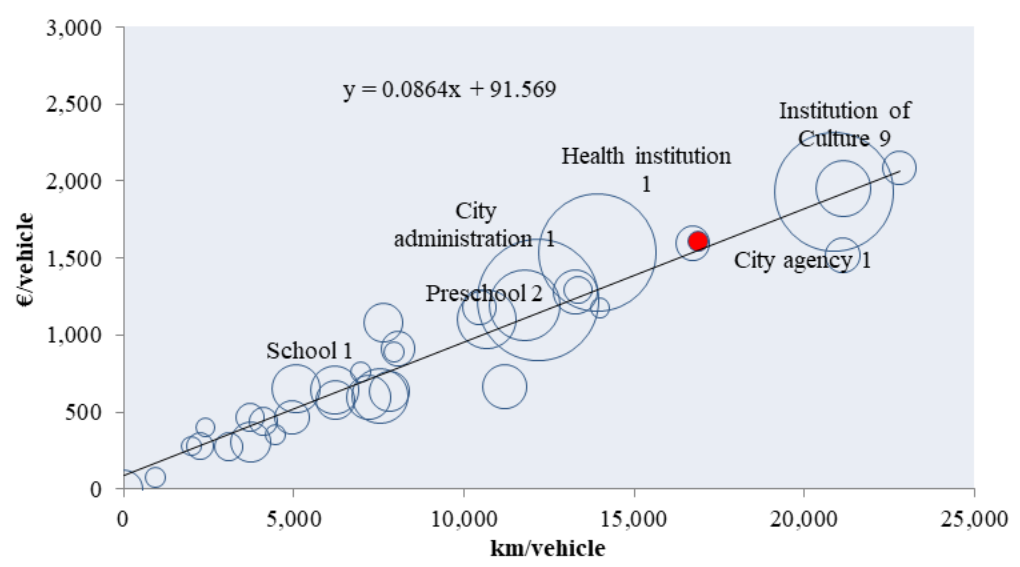

Figure 7. Enterprises after the implementation of the measure of matching the indicators resulting from internal benchmarking

The measure is implemented through:

- cooperation with the persons responsible for the fleet (fleet manager if that position exists)

- $\quad$ pointing to the fact that they have entered an internal benchmarking system in which their indicators are followed

- Introduction of the tracking/monitoring system to individual vehicles in order to locate potentially problematic points, ie vehicles and/or drivers

- Use of the monitoring system to locate good practice examples and awarding individual drivers

- The individual approach through provision of technical and consulting support in order to find ways to reduce fuel consumption in the fleets concerned.

After the implementation of the measure (Figure 7), it is noted that the referent fleet (red dot) is above the trendline, i.e. it isn't an example of good practice anymore, which means that (together with other fleets above the trendline) it becomes the subject of the next iteration of the same measure.

\subsection{Measure 2: Creation of a joint fleet, joint driving and driving pairing (car sharing in public institutions)}

This measure proposes the merging of fleets with less than $10.000 \mathrm{~km} /$ year/vehicle except in the case of fleets that are of interventional or emergency character. The creation of the joint fleet under the centralized management of experienced personnel in the traffic field is proposed. When analyzing data from Figure 7, it was noticed that half (20) of the total number of fleets per vehicle per year is making less than 10,000 kilometers. These fleets have a total of 61 vehicles i.e. on average 1.6 vehicles per fleet. On average, the vehicles from the mentioned group exceed 5.034 kilometers per year, or 20 kilometers per day or, at a speed of $25 \mathrm{~km} / \mathrm{h}$, only about 40 minutes per day in traffic. 


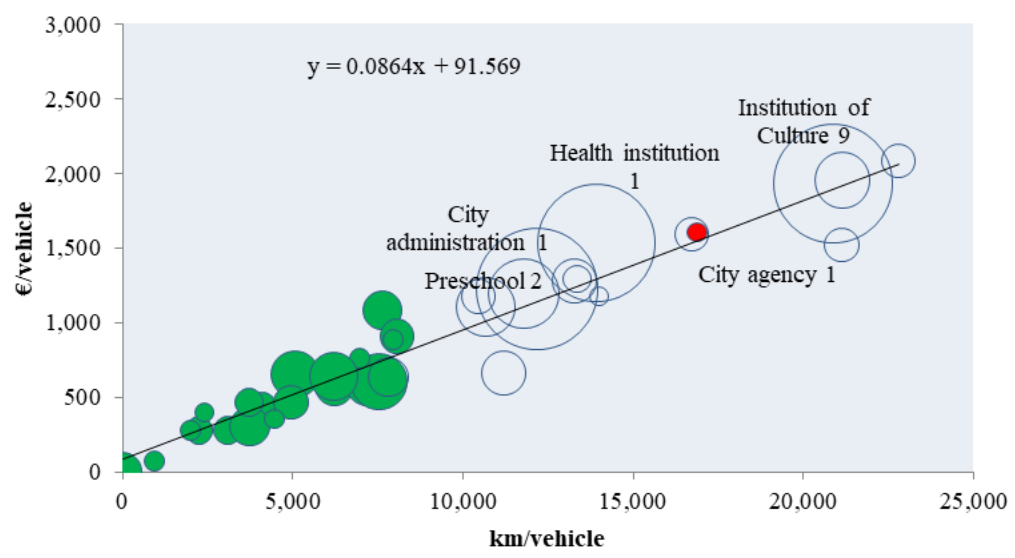

Figure 8. Car parks of public companies that exceed less than $10,000 \mathrm{~km} / \mathrm{year}$ per vehicle

Mentioned fleets are characterized by a high cost of exploitation, ie, high cost per mileage. This cost is the result of fixed costs (registration, insurance, part of maintenance costs, depreciation costs). It is estimated that in the presented circumstances, the price of the crossed kilometer is $0.35 €$ if the cost of depreciation is assumed to be 100,000 dinars per year per car. These costs per kilometer are very close to the price of taxi services in the city, which is $0.41 €$ per kilometer. The proposed establishment of a city fleet aims at the reduction of these fixed costs. The assumption is that the existing 61 vehicles can be replaced with up to 20 vehicles. The situation after the implementation of the measure is shown in Error! Reference source not found. (shaded fleet is hypothetical newly established fleet).

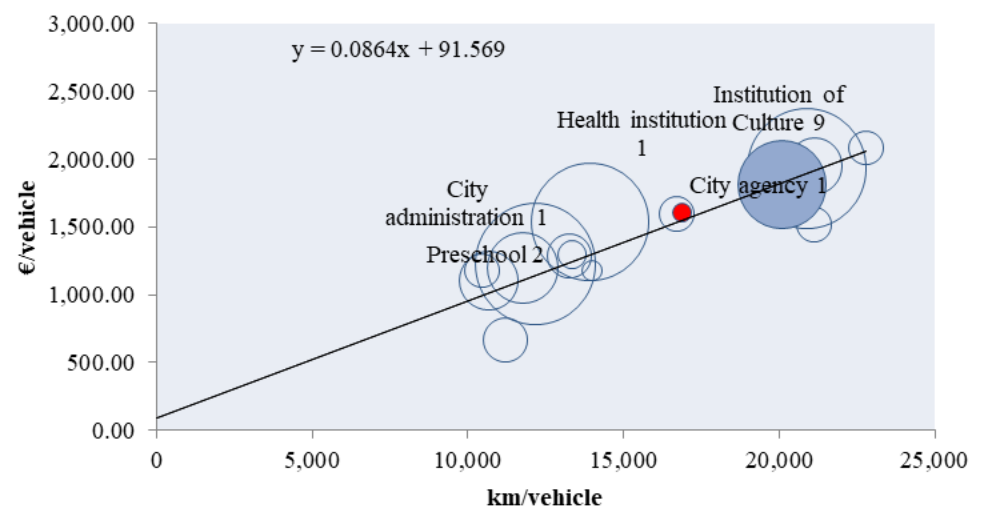

Figure 9. After the implementation of the measure of establishing a unified fleet (the colored "balloon" is a combined fleet with 20 vehicles)

Expected savings only through the reduction of fixed costs (maintenance, depreciation, registration and vehicle insurance) amounts to at least $50.000 €$ a year or about $5 \%$ of the total energy costs of all observed fleets in 2016. Additional savings can be expected as a result of the fact that the new fleet will be managed centrally, which can eventually be 
established as a new example of good practice in fleet management in public institutions in R. Serbia.

When the measure comes to life, other vehicles can be connected to the joint fleet, in the first place, the City Administration fleet should become a part of the joint fleet. Additionally, this measure has strong marketing potential, so the City should, with its example, lead the citizens to a new way of thinking in the direction of reducing the number of vehicles, reducing parking space burden, promoting car sharing, etc.

Furthermore, public institutions can improve the state of the so-called joint driving to work and to the most frequent destinations (eg. often conducted trips to Belgrade) as well as "pairing" their employees' driving with appropriate information and tools based on sharing information via the Internet or intranet.

The repayment period depends on the modality of the implementation of this measure. If a new fleet would be formed from existing vehicles, the costs would be due to the need for software and hardware for telematics. The assumption is that these costs would be compensated by selling the surplus vehicle (41 vehicles). In that case, a gradual transition to newer vehicles could be made, thus further improving the quality of the fleet.

It is expected that the repayment period will be very short, shorter than 3 months, which should be confirmed through a feasibility study.

\subsection{Measure 3: Establishment of eco-driving programs in the City Administration}

The measure involves the launching of eco-driving training programs for drivers employed by public companies who, because of the nature of their work, exceed a certain number of kilometers per year because eco-driving training is the easiest way to pay off for high mileage drivers. In accordance with experiences in similar situations, the minimum expected fuel savings is $5 \%$ (experiences in practice go up to $20 \%[4,5]$ ).

In order to facilitate the acquisition of knowledge and skills (and the likelihood that they will be longer in public enterprises and institutions), it is suggested that younger drivers first go through training. In the companies concerned, 158 persons are employed in the driver's position. 3/4 drivers of 158 high mileage drivers are employed in just three fleets and these three companies spent $€ 770,000$ on fuel per year. If one-third of the drivers ( 40 drivers) go through one-day training in the next two years, and if price per driver for that program is $100 €$ per driver/day, and the cost of lost working hours is estimated at about $12 €$ per participant (based on the average monthly income of 350 euros) it would save $2 \%$, i.e. the savings would be around $€ 15,000$, and the repayment period of the proposed measure would be up to 4 months. Furthermore, we should not ignore the side effects of such programs, such as improved safety, reduced tire, braking systems, and other maintenance costs. In order to measure the results of the proposed measure, it is necessary to combine it with Measure 1. i.e. data collecting. The driver rewarding and stimulation of the desired behavior can be founded from savings, which could accelerate the expected results.

\subsection{Measure 4: Tire pressure control}

Implementation of this measure should be centralized, by equipping one vehicle with a mobile compressor that would visit all vehicles in existing fleets for two months (325 vehicles in total). Estimated savings range from $0.6 \%$ (conservative) to $2 \%$ (optimistic) of total fuel consumption [6]. If the compressor is fitted with one of the vehicles withdrawn from the previously processed Measure 2 the investment could be minimal, amounting 300 $€$. If the operating cost of the operator is $2 €$ /hour gross and if operator needs 0.5 hours per 
vehicle, and the price of fuel, registration, insurance, and maintenance of the car amounted to $120 €$ per month the repayment period would be 6 months according to the most conservative scenario, and two months according to the optimistic scenario. The total estimated savings are $€ 7,000$ to $€ 22,000$ per year.

\subsection{Measure 5: Transition of a part of the petrol fleet to liquid petroleum gas}

For the implementation of this measure, vehicles and fleets in the M1 category exceeding $10,000 \mathrm{~km} /$ year per vehicle should be selected. The approximate cost of installing the device is $450 €$, while certification is $100 €$ per vehicle. The proposed measure covers a total of 120 vehicles with a total of 1,800,000 kilometers in 2016. The expected investment is $66,000 €$ with a repayment period of up to about one year (at the current price difference between gasoline and LPG, with an average fleet consumption of the said 120 vehicles of $9.31 / 100$ $\mathrm{km})$. The annual savings were estimated at $€ 110,000$ in the case that the measure is implemented on all 120 vehicles. The pace of implementation is subject to adjustment according to the resources available.

\section{CONCLUSION}

Instead of a conclusion, all expected savings are given in the following table. The abovementioned measures are characterized by short payback periods and could result in a relatively large saving of energy if measures are conducted consistently.

\begin{tabular}{|c|c|c|c|c|c|}
\hline Description & $\begin{array}{l}\text { Investment } \\
(€ / \text { year })\end{array}$ & $\begin{array}{l}\text { Potential } \\
\text { savings } \\
\text { (as \% of } \\
\text { the energy } \\
\text { used in } \\
2016 \text { ) }\end{array}$ & $\begin{array}{l}\text { Expected } \\
\text { savings } \\
(€ / \text { year })\end{array}$ & $\begin{array}{l}\text { Simple } \\
\text { payback } \\
\text { period } \\
\text { (years) }\end{array}$ & $\begin{array}{l}\text { Priority } \\
\text { level }\end{array}$ \\
\hline $\begin{array}{l}\text { Data collection, } \\
\text { internal } \\
\text { benchmarking, } \\
\text { transparency, the } \\
\text { publication of } \\
\text { collected } \\
\text { information and } \\
\text { rewarding of } \\
\text { good practice } \\
\text { examples }\end{array}$ & low & $3 \%$ & 30.000 & short & 1 \\
\hline $\begin{array}{l}\text { Creation of a } \\
\text { joint fleet, joint } \\
\text { driving and } \\
\text { driving pairing } \\
\text { (car sharing in } \\
\text { public } \\
\text { institutions) }\end{array}$ & $\begin{array}{l}\text { depends on } \\
\text { implementati } \\
\text { on strategy, it } \\
\text { can be low }\end{array}$ & $5 \%$ & 50.000 & $\begin{array}{l}\text { less than } \\
3 \\
\text { months }\end{array}$ & 1 \\
\hline $\begin{array}{l}\text { Establishment of } \\
\text { eco-driving } \\
\text { programs in the } \\
\text { City }\end{array}$ & 4.400 & $2 \%$ & $\min 15.000$ & $\begin{array}{l}\text { less than } \\
4 \\
\text { months }\end{array}$ & 2 \\
\hline
\end{tabular}


Administration

\begin{tabular}{lllllll}
\hline $\begin{array}{l}\text { Tire pressure } \\
\text { control }\end{array}$ & $\mathbf{3 . 5 0 0}$ & $\mathbf{2 \%}$ & & min 15.000 & $\begin{array}{l}\mathbf{6} \\
\text { months }\end{array}$ & $\mathbf{2}$ \\
\hline $\begin{array}{l}\text { The transition of } \\
\text { a part of the }\end{array}$ & & & & & & \\
petrol fleet to $\mathbf{6 6 . 0 0 0}$ & $\mathbf{U p}$ & to & $\mathbf{1 1 0 . 0 0 0}$ & one year & $\mathbf{3}$ \\
$\begin{array}{l}\text { liquid petroleum } \\
\text { gas }\end{array}$ & & & & & & \\
\hline
\end{tabular}

Since there is no energy efficiency program ongoing, expected total energy savings are estimated as (relatively large) $22 \%$. This number is suggesting both: a large space for energy management measures and that fleets are relatively poorly managed up to date. Here proposed approach is characterized by transparency, easy adaptation, and opportunities to monitor and follow the results of the implementation of proposed measures.

\section{REFERENCES}

[1] Sl. glasnik RS: "Pravilnik o podeli motornih i priključnih vozila i tehničkim uslovima za vozila u saobraćaju na putevima," br. 40/2012, 102/2012, 19/2013, 41/2013, 102/2014, 41/2015, 78/2015, 111/2015, 14/2016, 108/2016, 7/2017 - ispr., 63/2017, 45/2018, 70/2018, 95/2018 i 104/2018.

[2] Government of the Republic of Serbia: "The third Energy Efficiency Action Plan of the Republic of Serbia for the period until 2018," 2016.

[3] Banjac, M., et al.: "Priručnik za energetske menadžere za oblast opštinske energetike", Beograd: UNDP, 2016.

[4] Breithaupt, M., Eberz, O.: "Sustainable Transport: A Sourcebook for Policy-makers in Developing Cities," GTZ, 2005.

[5] Kazunori, K., Ryan, L.: "Transport Energy Efficiency, Implementation of IEA Recommendations since 2009 and next steps,” IEA, Paris, France, 2010.

Pearce, J., Hanlon, J.: "Energy Conservation From Systematic Tire Pressure Regulation," Energy Policy, vol. 35 (4), pp. 2673 - 2677, 2007. 